\title{
The digestion of hay administered to cows through rumen fistulas
}

\author{
By C. B. BAILEY* AND C. C. BALCH \\ National Institute for Research in Dairying, Shinfield, Reading
}

(Received 3 August 1960)

In a recent experiment to clarify the relationship between the act of eating and the subsequent pattern of salivary secretion (Bailey, 1959), the act of eating was prevented in three cows for a period of $2 \frac{1}{2}$ weeks by stuffing all their food into the reticulo-rumen through rumen fistulas. It was thought that this method of administering food might also find a use in studies on the function of the reticulo-rumen; the present communication describes some of the effects on the digestive processes.

\section{EXPERIMENTAL}

Three Shorthorn cows, with long-established fistulas in the dorsal sac of the rumen, were given $7 \mathrm{lb}$ of hay twice daily. The hay was chopped to approximately the size attained during normal mastication. The cows were either allowed to eat normally or were given the hay in small handfuls and at regular intervals deep into the ventral sac of the rumen during a period of time approximately equivalent to the time it took each animal to consume the same amount of hay when offered in the long state. Every attempt was made to ensure that each handful of hay was deposited in the fluid portion of the digesta in order to facilitate wetting of the dry material and to simulate the ensalivation which occurs during mastication (Balch, 1958). No difficulty was encountered in passing hay through the fistula and the animals exhibited no signs of distress either during this procedure or at other times. 'The cows passed normal faeces and drank normal amounts of water (see Table 2).

The cows were thoroughly accustomed to the hay before the experiment began. One week after the beginning of food administration through the fistula, the cows appeared to be well accustomed to the new routine. It was assumed that any changes that might have taken place in the characteristics of the digestion of the hay would be complete by this time and tests were carried out as follows, to show the presence or absence of such changes. On two successive days with each cow, samples of rumen fluid were removed through the fistula at I, 4, 8 and $\mathrm{I} 4 \mathrm{~h}$ after feeding and analysed for $\mathrm{pH}$, sodium, potassium, chloride, carbon dioxide, total volatile fatty acid (TVFA) and ammonia. Similar measurements were later obtained for the same cows when they were allowed to eat the test hay in the usual manner. At each sampling time, three separate samples of rumen fluid were taken immediately after the bung was removed

* Present address: Canada Department of Agriculture, Research Station, Lethbridge, Alberta, Canada. 
from the cannula in the rumen fistula. The first two samples were collected by thrusting two test-tubes deep into the ventral sac of the rumen, allowing them to fill with fluid, and immediately stoppering them so that no air space appeared between the meniscus and the bottom of the stopper. These two samples were used for the determination of $\mathrm{pH}$, carbon dioxide and ammonia, and this sampling procedure was adopted to minimize the loss of either of the volatile constituents. The third sample was collected immediately after the first two, by straining through gauze liquid digesta drawn from the same area of the ventral sac of the rumen as that from which the first two samples were taken. This sample was then centrifuged at $2900 \mathrm{~g}$ for 30 min and the supernatant liquid, which was fairly clear and devoid of all particulate matter, was poured off and retained for analysis. It was used for the determination of $\mathrm{Na}, \mathrm{K}, \mathrm{Cl}$ and TVFA.

$\mathrm{Na}$ and $\mathrm{K}$ were determined in an EEL model flame photometer. $\mathrm{Cl}$ was measured by the Van Slyke modification (see Hawk, Oser \& Summerson, I95I) of the method of Sendroy (1937). Carbon dioxide and ammonia were determined by the methods of Conway (1957). TVFA was determined by titration of a steam distillate of the rumen fluid. $\mathrm{pH}$ was measured with a Pye $\mathrm{pH}$ meter.

When the hay was given through the fistula, digestibility trials covering a 7 -day period were conducted on each animal, urine and faeces being separated with the apparatus of Balch, Bartlett \& Johnson (195I). The total contents of the reticulorumen were then removed through the fistula $7 \mathrm{~h}$ after the beginning of food administration in the morning, the contents were weighed, sampled for dry-matter determination and returned to the rumen. The procedure was repeated on 2 consecutive days for each cow. Continuous tracings of the rate of reticular contractions in each animal over a $24 \mathrm{~h}$ period were then obtained on a chart by a recording pen activated by a rubber tambour connected to an inflated toy balloon in the reticulum (Balch, Kelly \& Heim, I95I). The amount of time spent ruminating was estimated from these tracings and expressed as a percentage of the full $24 \mathrm{~h}$ period. Each of these characteristics was also measured in two of the three animals when the hay was being eaten in the usual way. Animal B died before all phases of the experiment were completed.

\section{RESULTS}

Values for the chemical composition of the rumen fluids are given in Table $\mathrm{r}$. On the whole, variations in the chemical characteristics were small and not consistently related to the method of food administration. There was, however, a tendency especially apparent with cows $\mathrm{B}, \mathrm{C}$ and $\mathrm{D}$ for the concentration of potassium in the rumen fluid to be lower when the hay was eaten than when it was given through the fistula.

The digestibility of the hay, the contents of the reticulo-rumen, the time spent ruminating and the amount of water drunk are given in Table 2; these values refer only to cows $A$ and $C$. The values show clearly that the digestibility of hay dry matter was the same whether hay was given through the fistula or was eaten; there were also no differences in the percentage of dry matter in the reticulo-ruminal contents. The amounts of dry matter in the reticulo-rumen were, however, considerably 
Vol. I 5

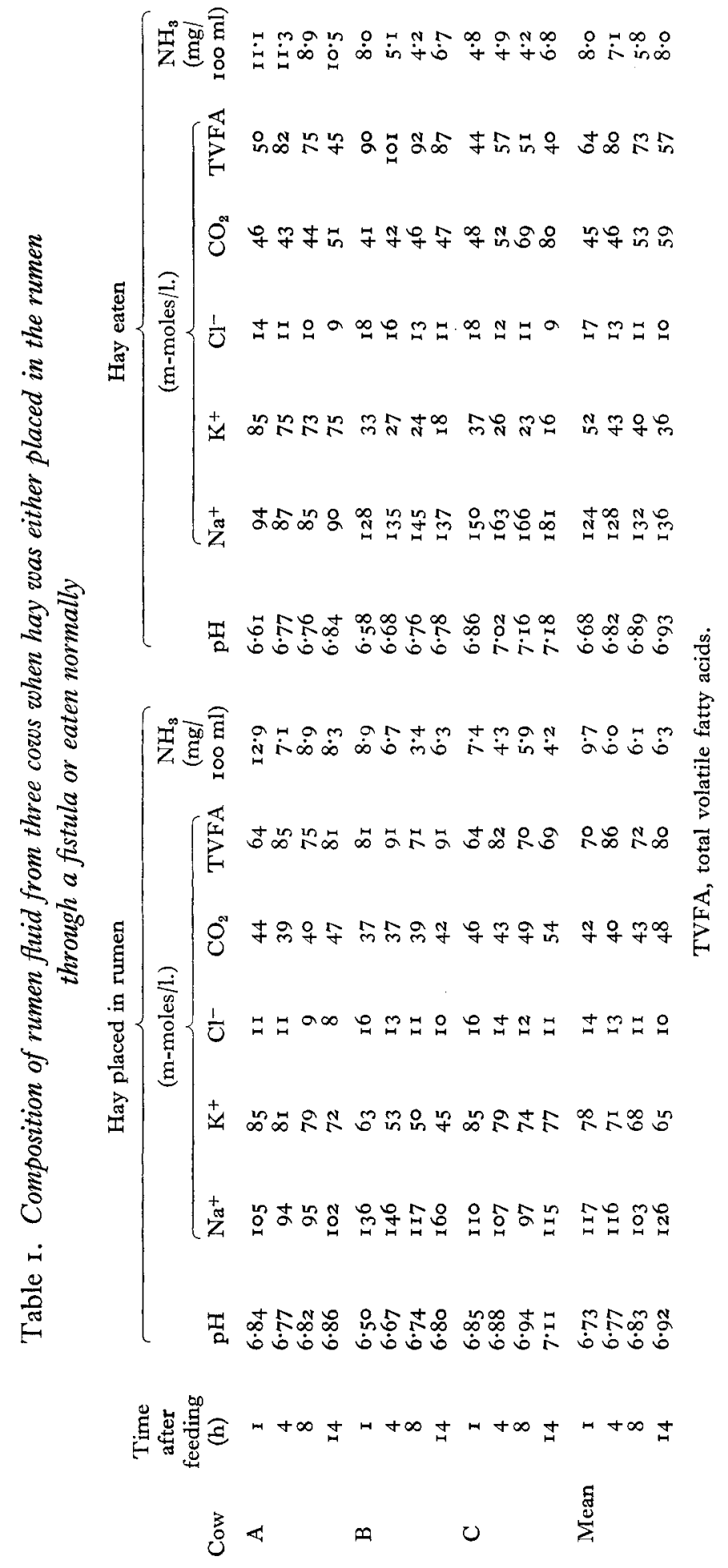


greater in both animals when they received their hay through the fistula. Moreover, the total time spent in rumination was increased from $3 \mathrm{I}$ to $44 \%$ of the $24 \mathrm{~h}$ in two animals when they were fed through the fistula. About half-way through the administration of a meal through the fistula, the animals began to ruminate and continued to do so until about $\mathrm{I}_{5} \mathrm{~min}$ after the end of the administration. This extra rumination was not sufficient to account for the greater total amount of rumination daily.

Table 2. Digestibility of hay, dry matter in contents of the reticulo-rumen, time spent ruminating and water intake in two cows when hay was either placed in the rumen through a fistula or eaten normally

\begin{tabular}{|c|c|c|c|c|c|c|}
\hline \multirow[b]{2}{*}{ Cow } & \multirow[b]{2}{*}{$\begin{array}{l}\text { Manner in which hay } \\
\text { was administered }\end{array}$} & \multirow[b]{2}{*}{$\begin{array}{c}\text { Digestibility } \\
\text { of dry } \\
\text { matter }(\%)\end{array}$} & \multicolumn{2}{|c|}{$\begin{array}{l}\text { Dry matter in the } \\
\text { reticulo-rumen contents }\end{array}$} & \multirow[b]{2}{*}{$\begin{array}{c}\text { Time spent } \\
\text { ruminating } \\
\text { as a } \\
\text { percentage } \\
\text { of } 24 \mathrm{~h}\end{array}$} & \multirow[b]{2}{*}{$\begin{array}{c}\text { Water } \\
\text { drunk } \\
\text { daily (lb) }\end{array}$} \\
\hline & & & $\mathrm{lb}$ & $\begin{array}{c}\text { As } \\
\text { percentage } \\
\text { of total } \\
\text { contents }\end{array}$ & & \\
\hline$A$ & $\begin{array}{l}\text { Eaten } \\
\text { Placed in rumen }\end{array}$ & $\begin{array}{l}64 \cdot 7 \\
64 \cdot 5\end{array}$ & $\begin{array}{l}13 \cdot 2 \\
16 \cdot 6\end{array}$ & $\begin{array}{l}10 \cdot 8 \\
10 \cdot 2\end{array}$ & $\begin{array}{l}3 I \cdot 2 \\
4 \cdot \cdot 0\end{array}$ & $\begin{array}{l}44 \\
40\end{array}$ \\
\hline $\mathrm{C}$ & $\begin{array}{l}\text { Eaten } \\
\text { Placed in rumen }\end{array}$ & $\begin{array}{l}59^{\circ} 4 \\
59 \cdot 5\end{array}$ & $\begin{array}{l}\text { II } \cdot I \\
I 3 \cdot 3\end{array}$ & $\begin{array}{l}\text { II } \cdot O \\
\text { II } \cdot I\end{array}$ & $\begin{array}{l}30 \cdot 7 \\
44 \cdot 2\end{array}$ & $\begin{array}{l}56 \\
59\end{array}$ \\
\hline Mean & $\begin{array}{l}\text { Eaten } \\
\text { Placed in rumen }\end{array}$ & $\begin{array}{l}62 \cdot 1 \\
62 \cdot 0\end{array}$ & $\begin{array}{l}12 \cdot 2 \\
14 \cdot 9\end{array}$ & $\begin{array}{l}10 \cdot 9 \\
10 \cdot 7\end{array}$ & $\begin{array}{l}3 I \cdot 0 \\
44 \cdot 1\end{array}$ & $\begin{array}{l}50 \\
50\end{array}$ \\
\hline
\end{tabular}

It is noteworthy that for the first I or 2 days after hay was first given through the fistula, the animals tended to become restive and watchful as the usual meal time approached, exactly as they did at the approach of a meal during normal feeding. This behaviour gradually became less marked until, 3-4 days later, no interest whatever was taken by the animal in the procedure of stuffing the hay into the rumen. When hay was placed before the animals in the usual manner after $2 \frac{1}{2}$ weeks of fistula feeding, they showed little inclination to eat. In fact, it was a full week before the most reticent of the three cows would consume the full $7 \mathrm{lb}$ of hay offered at each meal.

The administration of food through the fistula clearly did not influence the amount of water drunk by the cows.

\section{DISCUSSION}

The main change that could be detected when the animals were not allowed to eat but were given their hay directly into the rumen, was the increase in rumen contents $7 \mathrm{~h}$ after the beginning of the administration. It is likely that the rumen contained more digesta throughout the day than it would have done with normal feeding. This change may have resulted partly from the loss of the period of accelerated rumen emptying which has been found to occur during eating (Balch, 1958). It may also have been partly an indirect result of changes in the rate of breakdown of the digesta caused by the absence of the processes of crushing and ensalivation occurring during mastication. Saliva is often low in $\mathrm{K}$ and abolition of the rapid flow of saliva during eating was probably the main cause of the high concentrations of $\mathrm{K}$ in rumen contents when cows $\mathrm{B}, \mathrm{C}$ and $\mathrm{D}$ were receiving hay through the fistula. The absence of these 
processes could lead to a delayed bacterial attack on the hay and a delayed rate of passage of food.

To what extent the increase in the contents of the reticulo-rumen implied a slowing in the rate of passage of residues through the rumen is not clear. The composition of the rumen contents suggests that there was no marked change in the rate of breakdown of the food in that compartment. It was noticed, however, that notwithstanding the care with which the hay was placed in the fluid portion of the rumen contents the material was not wetted immediately. Further it was evident that the mass of digesta in the rumen, $\mathrm{I} \frac{1}{2} \mathrm{~h}$ after the last portion of hay was so given, contained a far larger proportion of intact strands of hay than when the animal had eaten the hay. This observation would suggest that degradation of the hay particles was delayed. It was especially interesting in the light of the finding that rumination began even while hay was being placed in the rumen. It would also be of interest to know whether the increased total amount of rumination was related to the increased load of reticuloruminal digesta.

As an experimental technique, the administration of food through the rumen fistula may have occasional uses, provided the differences from normal eating, summarized above, are realized. These differences are likely to have been greater with our all-roughage diet than they would be with many other diets. In comparison with hay, succulent or finely ground foods given through the fistula would be expected to evoke smaller deviations from the normal pattern of rumen function.

\section{SUMMARY}

I. Three cows received $\mathrm{I} 4 \mathrm{lb}$ hay daily in two meals. Either they were allowed to eat the hay normally or it was coarsely chopped and pushed by hand through rumen fistulas and into the ventral sac of the rumen. The animals showed no discomfort when hay was placed in the rumen.

2. When the cows received their hay through the fistula, the $\mathrm{pH}$ and the concentrations of sodium, potassium, chloride, carbon dioxide, total volatile fatty acids and ammonia in the rumen contents differed little from those found when they ate the hay. There was, however, some tendency for the level of $\mathrm{K}$ in the rumen fluid to be high while the cows received their hay through the fistula.

3. The digestibility of the dry matter of the hay and the percentage of dry matter in the contents of the reticulo-rumen were not changed when the hay was administered through the fistula, but the amount of dry matter in the reticulo-rumen was increased. Moreover, in each $24 \mathrm{~h}$ the amount of time spent ruminating increased approximately from $30 \%(43 \circ \mathrm{min})$ with normal eating to $44 \%(63 \circ \mathrm{min})$ with hay placed in the rumen.

4. It is concluded that provided these slight changes in rumen function are appreciated the administration of food through the fistula might have occasional use in experiments. 
We are grateful to $\mathrm{Mr} \mathrm{V}$. W. Johnson and his assistants for help in the management of the animals.

The work reported in this paper was performed during the tenure by one of us (C.B.B.) of a scholarship from the Royal Commission for the Exhibition of $185 \mathrm{I}$.

\section{REFERENCES}

Bailey, C. B. (1959). Proc. Nutr. Soc. 18, xiii.

Balch, C. C. (1958). Brit. F. Nutr. 12, 330.

Balch, C. C., Bartlett, S. \& Johnson, V. W. (195I). F. agric. Sci. 4I, 98.

Balch, C. C., Kelly, A. \& Heim, G. (195I). Brit. F. Nutr. 5, 207.

Conway, E. J. (1957). Microdiffusion Analysis and Volumetric Error, $4^{\text {th }}$ ed. London: Crosby Lockwood \& Son Ltd.

Hawk, P. M., Oser, B. L. \& Summerson, W. H. (195I). Practical Physiological Chemistry, I2th ed. London: J. and A. Churchill.

Sendroy, J. Jr. (1937). F. biol. Chem. r2o, 405. 